\title{
Estimation of defence related compounds in healthy and malformed vegetative tissues of mango in five states of northern India induced in response to low temperature and high relative humidity
}

\author{
V. RANI* AND G. BAINS \\ Department of Plant Physiology, College of Basic Science and Humanities, G.B. Pant University of Agriculture \\ and Technology, PANTNAGAR (UTTARAKHAND) INDIA
}

\begin{abstract}
Mango malformation disease occurs as the result of accumulation of ethylene under stress in plant parts following infection with Fusarium mangiferae. In response to fungal infection several defence related compounds like total phenols, polyphenol oxidase and lipooxygenase accumulate in plant parts. In malformed tissue samples of five commercial mango varieties collected from different states recorded an increase in total phenol content and a reduced polyphenol oxidase and lipoxygenase activity.
\end{abstract}

Key Words : Mango malformation, Total phenols, Polyphenol oxidase, Lipooxygenase, Ethylene, Fusarium mangiferae

View Point Article : Rani, V. and Bains, G. (2017). Estimation of defence related compounds in healthy and malformed vegetative tissues of mango in five states of northern India induced in response to low temperature and high relative humidity. Internat. J. agric. Sci., 13 (1) : 1-8, DOI:10.15740/HAS/IJAS/13.1/1-8.

Article History : Received : 16.09.2016; Revised : 21.10.2016; Accepted : 01.12 .2016

\footnotetext{
* Author for correspondence:
} 